Author

Margaret Hellard Email: hellard@burnet.edu.au

Burnet Institute

Centre for Population Health

Melbourne

Victoria

Australia

Monash University

Department of Epidemiology and Preventative Medicine

Melbourne

Victoria

Australia

Alfred Hospital

Department of Infectious Diseases

Melbourne

Victoria

Australia

Author

Alexander Thompson Email: alexander.thompson@svha.org.au

St. Vincent's Hospital Melbourne

Department of Gastroenterology

Fitzroy

Victoria

Australia

University of Melbourne

Department of Medicine

Melbourne

Victoria

Australia

Corresponding Author

Nick Scott

Email: Nick.Scott@burnet.edu.au Burnet Institute

Centre for Population Health

Melbourne

Victoria

Australia

Monash University

Department of Epidemiology and Preventative Medicine

Clayton

Victoria

This is the author manuscript accepted for publication and has undergone full peer review but has not been through the copyediting, typesetting, pagination and proofreading process, which may lead to differences between this version and the Version of Record. Please cite this article as doi:

$10.1111 /$ jgh.13223

This article is protected by copyright. All rights reserved. 


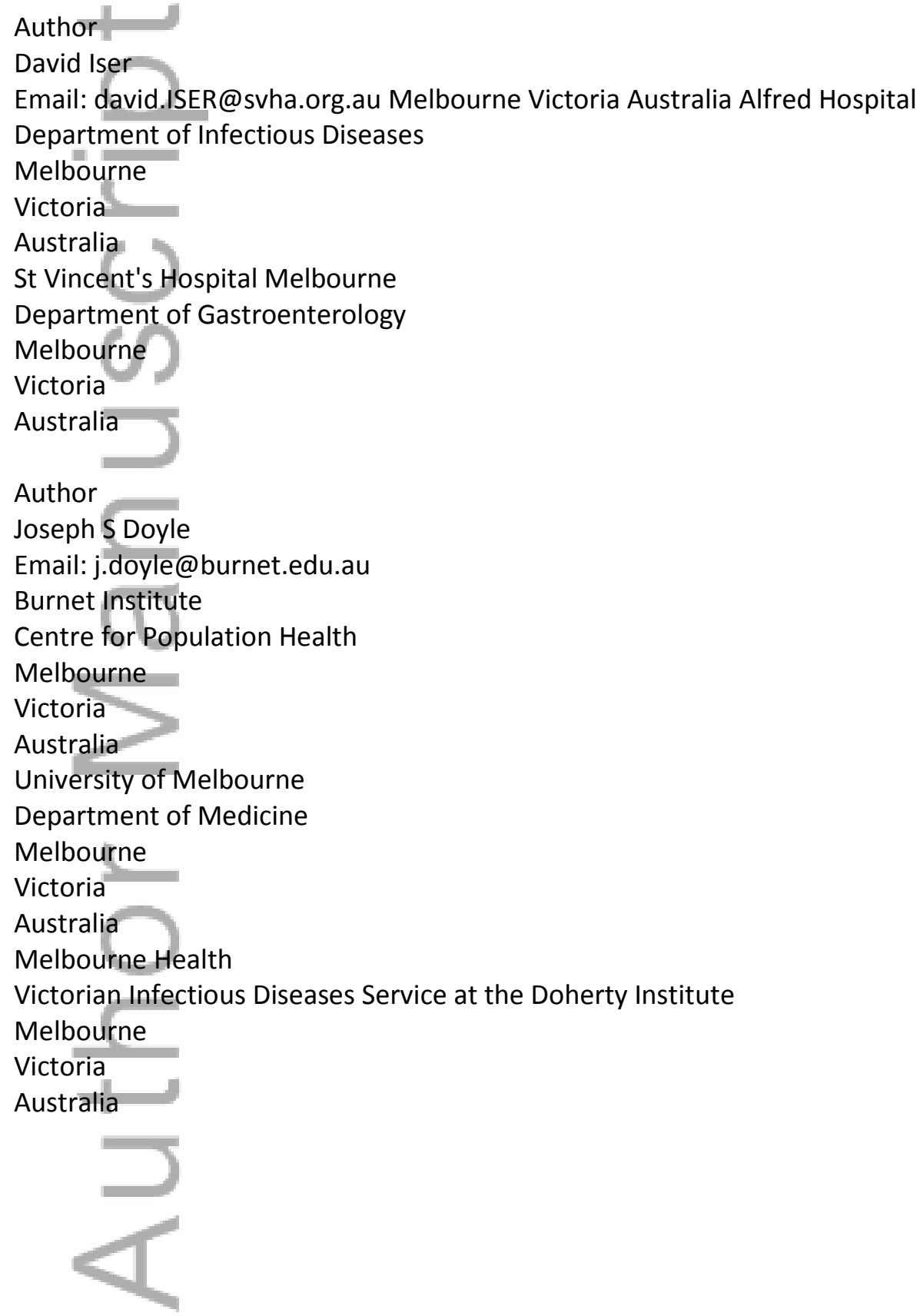




\section{COST-EFFECTIVENESS OF TREATING CHRONIC HEPATITIS C VIRUS WITH DIRECT-ACTING \\ ANTIVIRALS IN PEOPLE WHO INJECT DRUGS IN AUSTRALIA}

\section{Abstract}

Background and Aim: Reducing the burden of hepatitis C virus (HCV) related liver disease will require treating people who inject drugs (PWID), the group at most risk of infection and transmission. We determine the cost-effectiveness of treating PWID with interferon-free direct-acting antiviral therapy in Australia.

Methods: Using a deterministic model of HCV treatment and liver disease progression, including a fixed rate of re-infection, the expected healthcare costs and quality-adjusted life years (QALYs) of a cohort of newly HCV-infected PWID were calculated for: no treatment; treatment after initial infection ('early-treatment'); and treatment prior to developing compensated cirrhosis ('latetreatment'). Incremental cost-effectiveness ratios (ICERs) were used to compare scenarios.

Results: Late-treatment was cost-effective compared to no treatment, with a discounted average gain of $2.98(95 \% \mathrm{Cl} 2.88-5.22)$ QALYs for an additional cost of $\$ 15,132(\$ 11,246-18,922)$, giving an ICER of $\$ 5,078(\$ 2,847-5,295)$ per QALY gained. Compared to late-treatment, early-treatment gained a further discounted average of $2.27(0.58-4.80)$ QALYs for $\$ 38,794(\$ 34,789-41,367)$, giving an ICER of $\$ 17,090(\$ 2,847-63,282)$, which was cost-effective in approximately $90 \%$ of Monte-Carlo uncertainty simulations. For every 100 newly HCV-infected PWID, there were an estimated 40 (3956) eventual liver related deaths without treatment, compared to 7 (6-11) and 8 (7-13) with earlytreatment and late-treatment available respectively.

Conclusions: Treating HCV-infected PWID with new therapies is cost-effective, and could prevent a significant number of liver related deaths. Although late-treatment was the most cost-effective option, the cost per QALY gained for early-treatment compared to late-treatment is likely to be below unofficial Australian willingness to pay thresholds.

This article is protected by copyright. All rights reserved. 
Keywords: hepatitis C virus; direct-acting antivirals; cost-effectiveness; people who inject drugs

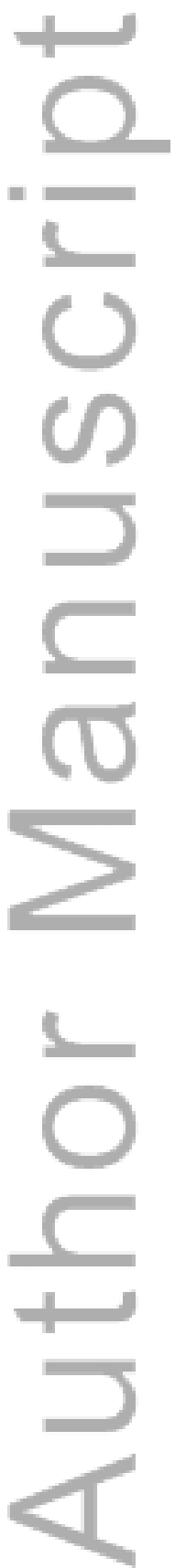

This article is protected by copyright. All rights reserved. 


\section{Introduction}

Hepatitis $\mathrm{C}$ virus (HCV) is a major global health problem affecting approximately 170 million people worldwide (1). In Australia there are an estimated 230,000 people chronically infected with HCV (2), and as with most developed countries, people who inject drugs (PWID) remain the group at greatest risk of infection (1-3). The prevalence of HCV antibodies among PWID varies globally, ranging from $10 \%$ to $97 \%(4,5)$; however this may be up to $25 \%$ higher than the prevalence of current HCV infection (6) which is rarely determined in epidemiological studies. Nevertheless, the prevalence of HCV infection in PWID is high in many countries $(4,5)$, and treating PWID of their infection has been identified as having the most significant impact on the overall future burden of disease $(7,8)$.

The considerable side effects and low cure rates of interferon-based HCV treatments $(9,10)$ have contributed to persistently low treatment amongst PWID globally. In Australian residents, uptake is estimated at only $2,000-3,500$ individuals annually; less than $2 \%$ of all chronically infected individuals (11-13). Most chronic HCV infections are asymptomatic for many years, however prolonged untreated infection poses a substantial risk of progression to advanced liver disease (14). Continued poor uptake of treatment is likely to result in a substantial future healthcare burden as those who are chronically infected age (15). In particular as the risk of primary liver cancer is ten-fold higher in people aged 45-64 years than in those aged 25-44 years (16).

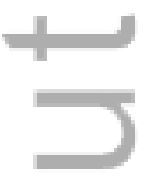

The advent of highly effective direct-acting antiviral treatment (DAAs), with $90 \%$ cure rates, improved tolerability and a comparably short duration of therapy (up to 12 weeks) (17-19) has shifted attitudes towards treatments. However, even in countries like Australia that have a wellresourced health system, DAAs as currently priced are yet to be approved either in full or part for subsidy on the Pharmaceutical Benefits Scheme (PBS) and will place a substantial burden on

This article is protected by copyright. All rights reserved. 
government medication outlays if and when they are listed. Despite their clear benefits, particularly among PWID, few studies have determined their cost-effectiveness in this population. Data relating to a country's healthcare system must be weighed against local treatment costs and re-infection probabilities to provide useful evidence for health policy.

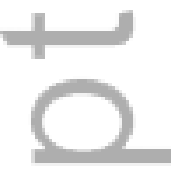

Many models of the cost-effectiveness of DAAs are not applicable to PWID (20), given their significant rates of HCV re-infection (21) and differences in mortality and quality of life compared to the general population (22). Previous models have been used to determine the cost-effectiveness of treating PWID with older generation therapies, using a fixed rate of re-infection $(23,24)$ or a dynamic transmission model including prevention benefits (25). In this paper we use a similar approach by assuming a fixed rate of re-infection (calibrated by baseline prevalence) to determine the cost-effectiveness of treating PWID with DAAs in Australia. In particular, we compare treating PWID at the onset of their infection or delaying treatment until their liver disease has progressed to moderate fibrosis. Treatments have proven to be equally effective at this stage of liver disease and delaying treatment may potentially save on costs, in particular since the slow progression of liver disease means that a proportion of PWID will have ceased injecting drug use by the time they are eligible for late-treatment, reducing re-infection and re-treatment rates.

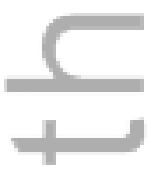

Methods

Model description

We used a closed compartmental model of liver disease progression and treatment with a fixed rate of HCV re-infection (Figure 1).

This article is protected by copyright. All rights reserved. 
METAVIR scores were used to classify stages of liver disease, and individuals were distinguished as either: acutely infected (A); chronically infected with liver fibrosis in stage (F0-F4); chronically infected with decompensated cirrhosis (DC); chronically infected with hepatocellular carcinoma (HCC); first year or more than one year post liver transplant (LT1 and LT2 respectively); chronically infected and in treatment achieving sustained viral response (SVR) (TO and T2-treated from liver fibrosis stage FO and F2 respectively); or susceptible (SO-achieving spontaneous clearance or SVR spontaneously from the acute stage or through treatment from liver fibrosis stage F0; S2-achieving SVR from treatment in liver fibrosis stage F2). Individuals were also classified by injecting drug use status ( $\mathrm{i}=1$ indicating current PWID, $\mathrm{i}=0$ indicating former PWID) and whether they had previously failed treatment ( $\mathrm{j}=0$ indicating never failed, $\mathrm{j}=1$ indicating previously failed).

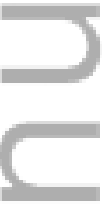

The model was started with a cohort of newly infected PWID who had not previously failed treatment $\left(\mathrm{FO}_{1,0}=100\right)$, who were assumed to be 23.5 years old - the mean age of first injection (26) + the average time to infection (21), see Table 1. People in the model moved between identical compartments of the i stratification due to cessation or relapse into injecting drug use at fixed rates $\eta$ and $r_{\text {relapse }}$ respectively. All-cause mortality occurred for each compartment at an age dependent rate $\mu$ (Table 1), and mortality rates for the DC, HCC, LT1 and LT2 compartments were increased by $r_{\text {DCdeath }}, r_{\text {HCCdeath }}, r_{\text {LT1death }}$ and $r_{\text {LT2death }}$ respectively. Liver disease progressed at rates obtained from the literature (Table 2), and average liver transplant wait times were $1 / r_{\text {DCLT }}$ and $1 / r_{\text {HCCLT }}$ from the DC and HCC stages respectively.

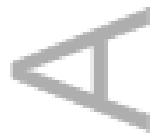

The availability of treatment was scenario dependent (see Scenarios section), but when available, a proportion $\mathrm{p}_{\mathrm{com}}$ of PWID who were offered treatment were assumed to adhere, so that for a given treatment efficacy $\alpha$, the proportions $\alpha$ and $\alpha p_{\text {com }}$ of former PWID and current PWID respectively

This article is protected by copyright. All rights reserved. 
achieved SVR when offered treatment. Individuals who were assumed to achieve SVR moved to the treatment compartment matching their liver fibrosis stage (T0 or T2) and after a period $\omega$, achieved SVR and moved to the corresponding susceptible compartment ( $\mathrm{SO}$ or S2). The remaining proportions of current and former PWID (1- $\alpha$ and 1- $\alpha p_{\text {com }}$ respectively) who failed treatment were moved to the $\mathrm{j}=1$ stratification and where they continued liver disease progression without any retreatment. The increasing number of fixed-dose combination therapies on the market means that alternate options are likely to be available in the future to cure these patients in an extended treatment regimen, resulting in a higher treatment efficacy; both extended treatment duration and higher efficacy treatments are tested in the sensitivity analysis.

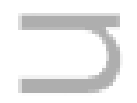

PWID who achieved SVR could become re-infected at a fixed rate $\pi$, which was calculated using a separate model where incidence was estimated based on prevalence and other model parameters (Appendix A). PWID who became re-infected after successful early-treatment spent a period $1 / \mathrm{r}_{\mathrm{AF} 0}$ in the acute stage before a proportion $\delta$ spontaneously cleared infection and became susceptible, while the remaining (1- $\delta$ ) became chronically infected and entered the F0 compartment. PWID who became re-infected after successful late-treatment entered the F2 compartment, and were assumed to not spontaneously clear infection. Spontaneous clearance following re-infection has been observed, however at a reduced rate that is currently unclear, and this assumption will lead to slightly higher estimates of re-infection for this group and conservative estimates of costeffectiveness. Where re-infection occurred, individuals were able to be re-treated.

$<$ Figure 1>

\section{Parameters}

This article is protected by copyright. All rights reserved. 
As the cost of DAAs is currently unclear in Australia, we assumed a base scenario of $\$ 50,000$ (for 12 weeks of treatment) for genotype 1 and 2 , and $\$ 100,000$ (for 24 weeks of treatment) for genotype 3-averaged over the Australian genotype distribution (Table 1)-and tested upper and lower bounds of $\$ 100,000$ for all genotypes and $\$ 10,000$ for all genotypes in the sensitivity analysis. Healthcare and other costs associated with disease management or treatment were determined in consultation with hepatology and infectious diseases experts (Table 3). For a typical patient in each liver disease stage, specialist and general practitioner consultation frequency, as well as the frequency that tests and procedures would be requested were agreed upon for the current standard of care. The costs of each consultation, test or procedure were then taken from the Medicare Benefits Scheme (27) and the Pharmaceutical Benefits Scheme (28). A further breakdown is provided in Appendix B.

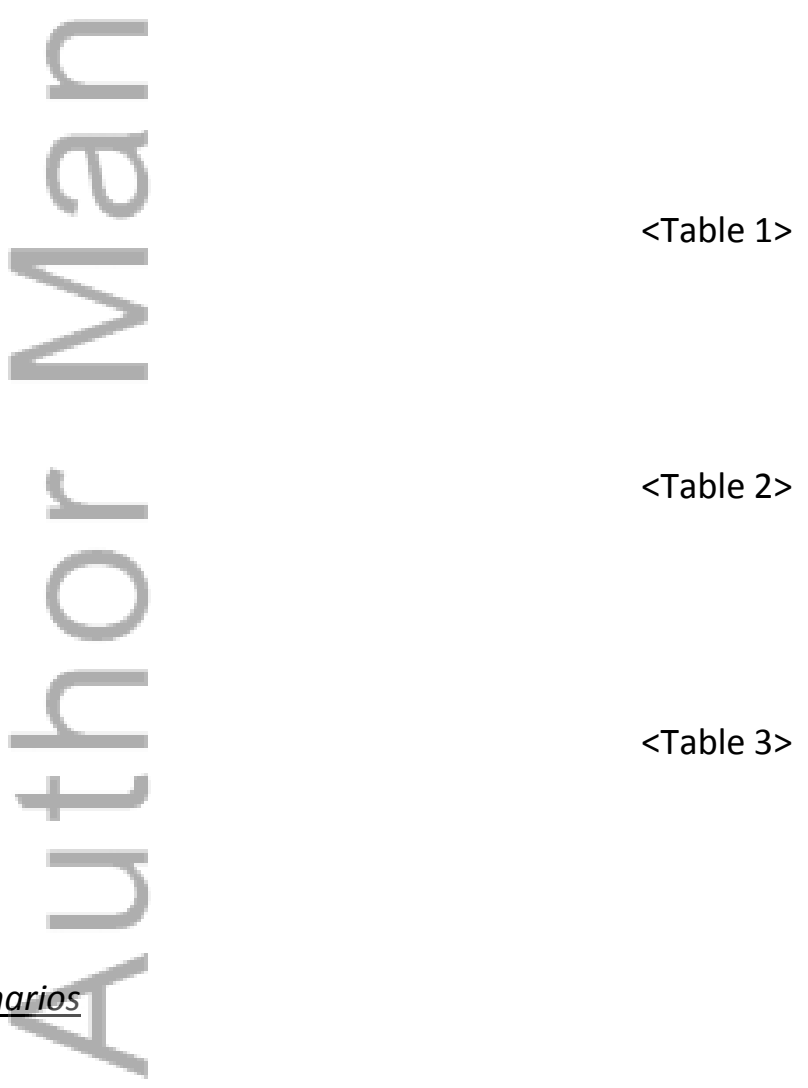

No antiviral treatment

No treatments were available. The average discounted person years spent in each compartment by a cohort member (i.e. a newly infected PWID) was calculated by integrating the size of each

This article is protected by copyright. All rights reserved. 
compartment over time for the first 100 years, discounted with a continuously compounding rate of $3 \%$ per annum (the lower bound recommended in Australia (47), with an upper bound of $5 \%$ also tested) and then dividing by the cohort size. Discounted average costs and Quality Adjusted Life Years (QALYS) per infected PWID were calculated by multiplying the average discounted personyears spent in each compartment by the associated annual costs and heath utilities (Table 3).

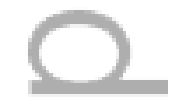

$=$

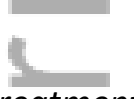

Early-treatment

Early-treatment was defined as treatment from the F0 stage in order to give an upper bound on cost-effectiveness-without treatment these patients have the most delayed and therefore discounted healthcare costs. This was implemented by initially offering the entire cohort treatment, and for the purposes of determining the cost-effectiveness of treating at this stage it was assumed that everyone initially commenced treatment: a proportion $\alpha \mathrm{p}_{\text {com }}$ were moved to the $\mathrm{TO}_{1,1}$ compartment, while the remaining (1- $\alpha \mathrm{p}_{\mathrm{com}}$ ) failed treatment and stayed in the $\mathrm{FO}_{1,1}$ compartment. The model was run and costs and QALYs were calculated, including the discounted costs of initial and subsequent treatments.
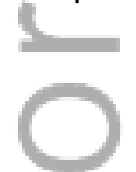

Late-treatment

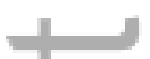

Late-treatment (to prevent advanced liver disease) was defined as treating on transition from F2 to F3, as limitations in the accuracy of the Fibroscans typically used to identify disease stage mean that a later cut-off would fail to prevent some cases. This was implemented by offering the entire cohort treatment as they moved from liver fibrosis stage F2 to F3 (again assuming everyone commenced): when making the transition from F2 to F3 a proportion $\alpha \mathrm{p}_{\text {com }}$ were moved to the T2 compartment, while the remaining (1- $\left.\alpha \mathrm{p}_{\text {com }}\right)$ failed treatment and continued liver disease progression to the F3 compartment. The model was run and costs and QALYs were calculated.

This article is protected by copyright. All rights reserved. 


\section{$\underline{\text { Sensitivity analysis }}$}

To test model robustness, a Monte Carlo uncertainty analysis was conducted. Using the uncertainties of individual parameters-parametrised as probability distributions (Table 2 and Table 3) -1000 simulations were undertaken using random, independent parameter draws. $95 \%$ confidence intervals $(95 \% \mathrm{Cls})$ for the discounted cost per infected person, QALYs per infected person, life expectancy, liver-related deaths and ICER estimates were taken as the central 95 percentiles of the resulting 1000 outputs. Henceforth, outcomes presented are from point estimate parameters and $95 \% \mathrm{Cls}$ have been taken from the uncertainty analysis results.

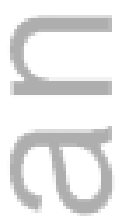

One-way sensitivity analyses were also undertaken to test the impact on ICERs when: the cost of treatment was either $\$ 100,000$ for all genotypes or $\$ 10,000$ for all genotypes; the annual probability of re-infection was 0.08 or 0.16 instead of 0.11 (corresponding to chronic HCV prevalence of $40 \%$ or $60 \%$ respectively, instead of $50 \%$ - see Appendix A); the discounting rate was increased from $3 \%$ to $5 \%$; no retreatment was allowed; the SVR rate was changed from $90 \%$ to either $70 \%$ or $99 \%$; the length of injecting career was halved from 17 to 8.5 years; former PWID were unable to relapse into active injecting; former PWID were unable to relapse into active injecting and the length of injecting career was halved; treatment duration was set to 12 or 24 weeks for all genotypes instead of the 16 week weighted average; and the health utility following late-treatment was 0.770 instead of 0.930 .

\section{$\underline{\text { Results }}$}

\section{Cost-effectiveness estimates}

This article is protected by copyright. All rights reserved. 
Compared to no treatment, late-treatment was the most cost-effective option, however earlytreatment was the most effective option in terms of quality of life years gained (Table 4). Latetreatment resulted in a discounted average gain of $2.98(95 \% \mathrm{Cl} 2.88-5.22)$ QALYs for an additional cost of $\$ 15,132(95 \% \mathrm{Cl} \$ 11,246-18,922)$ compared to no treatment-giving an ICER of $\$ 5,078(95 \% \mathrm{Cl}$ $\$ 2,847-5,295)$ per QALY gained. In contrast, early-treatment resulted in a discounted average gain of $5.25(95 \% \mathrm{Cl} 3.94-9.33)$ QALYs for an additional cost of $\$ 53,926(95 \% \mathrm{Cl} \$ 51,115-55,781)$ compared to no treatment-giving an ICER of $\$ 10,272(95 \% \mathrm{Cl} \$ 5,689-13,690)$ per QALY gained.

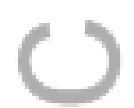

Compared to late-treatment, early-treatment gained a further discounted average of $2.27(95 \% \mathrm{Cl}$ 0.58-4.80) QALYs for $\$ 38,794$ (95\%Cl $\$ 34,789-41,367)$, giving an ICER of $\$ 17,090$ (95\%Cl $\$ 2,847-$ $63,282)$. For a willingness to pay threshold of $\$ 50,000$ per QALY gained this was cost-effective in approximately $90 \%$ of Monte Carlo uncertainty analysis simulations (Figure 2, bottom left), but was not cost-effective in some simulations and so this result is not statistically significant at the $95 \%$ level (see discussion).

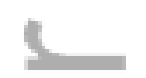

For every 100 newly HCV-infected PWID, there were an estimated $40(95 \% \mathrm{Cl} 39-56)$ eventual liver related deaths when no treatment was available, compared to $7(95 \% \mathrm{Cl} 6-11)$ and $8(95 \% \mathrm{Cl} 7-13)$ when early-treatment and late-treatment were available respectively.

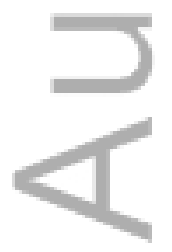

$<$ Table 4>

$<$ Figure 2>

This article is protected by copyright. All rights reserved. 


\section{$\underline{\text { Sensitivity analysis }}$}

Changes to the cost of DAAs had the largest effect on cost-effectiveness estimates, but even at $\$ 100,000$ per treatment course the ICERs for early-versus late treatment and late versus no treatment ( $\$ 37,778$ and $\$ 13,259$ per QALY gained respectively) were below the unofficial Australian willingness to pay threshold of $\$ 50,000$ per QALY gained. Further, when the cost of DAAs was reduced to $\$ 10,000$ for all genotypes, both early- and late-treatment were more effective and less costly than no treatment, and early-treatment had an ICER of only \$1,365 per QALY gained compared to late-treatment.

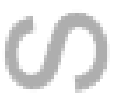

Excluding the potential for former PWID to relapse into active injecting is a conservative assumption (48), which increased ICER estimates by $97 \%$ (from $\$ 17,090$ to $\$ 37,714$ ) for early-treatment compared to late-treatment, but only increased ICER estimates by $2 \%$ (from $\$ 5,078$ to $\$ 5,188$ ) for late-treatment compared to no treatment. This is because if HCV-infected former PWID cannot relapse into the pool of injectors, then a greater infection parameter $\pi$ is required to calibrate prevalence, leading to higher re-infection rates amongst current PWID. For the early-treatment (ron scenario, this means that more of the cured PWID are likely to become re-infected, requiring additional treatment costs and facing the possibility of failing treatment and experiencing poorer health outcomes; however conversely, for the late-treatment scenario, by the time advanced liver disease (and hence treatment) is obtained, most PWID have ceased injecting and with no chance of relapse or re-infection will experience similar outcomes. For the same reasons, when the length of injecting career was halved the ICER increased for early-treatment and decreased for late-treatment (although by less than $10 \%$ in each case), and these effects compounded when the length of injecting career was halved and former PWID were unable to relapse. 
If the annual probability of re-infection was increased from 0.11 to 0.16 (initial prevalence increased from $50 \%$ to $60 \%$ ), ICERs for the early- versus late-treatment and late-treatment versus no treatment scenarios increased by $24 \%$ (by $\$ 4,119$ ) and $26 \%$ (by $\$ 1,297$ ) respectively, again as a result of a greater infection parameter. Conversely, if the annual probability of re-infection was decreased from 0.11 to 0.08 (initial prevalence decreased from $50 \%$ to $40 \%$ ), ICERs for early-versus late-treatment and late-treatment versus no treatment decreased by $17 \%(\$ 2,874)$ and $18 \%(\$ 895)$ respectively.

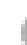

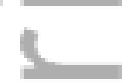

Variations in the ICERs for early-versus late-treatment and late-treatment versus no treatment as a result of changes to the discounting rate, re-treatment availability, treatment efficacy, treatment duration and health utility following late-treatment were logical and within sensible limits.

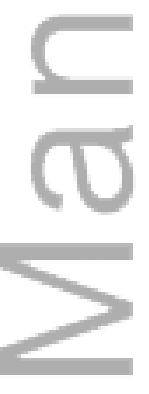

$<$ Figure 3>

\section{Discussion}

Using a cohort model of HCV treatment, liver disease progression and re-infection we have determined that it is cost-effective to treat PWID with DAAs in Australia. Late-treatment was the most cost-effective option, with an ICER of $\$ 5,078$ per QALY gained compared to no treatment, while early-treatment had an ICER of $\$ 10,272$ per QALY gained compared to no treatment and $\$ 17,090$ per QALY gained compared to late-treatment.

As the time taken for liver disease to progress to an advanced stage was comparable to the length of injecting career, re-infection rates were lower after late-treatment than after early-treatment due to cessation of injecting. PWID that were treated early therefore had an increased likelihood of

This article is protected by copyright. All rights reserved. 
becoming re-infected, failing re-treatment and progressing to advanced liver disease. For some combinations of parameters in the uncertainty analysis this resulted in early-treatment gaining only slightly more QALYs than late-treatment, while costing substantially more (Figure 2, top and bottom left). As a result, in approximately $10 \%$ of parameter combinations in our uncertainty analysis, earlytreatment had an ICER greater the $\$ 50,000$ per QALY gained compared to late-treatment, owing to sensitivities in the model parameters for the length of injecting career and rates of relapse into injecting drug use among former PWID.

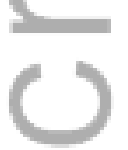

These estimates are likely to be conservative, and treating PWID with DAAs in Australia may be even more cost-effective than predicted. Firstly, the costs associated with patients who have decompensated cirrhosis or hepatocellular carcinoma in our model are underestimates: healthcare management costs associated with these disease stages were based on minimum requirements agreed upon by specialists (Appendix 2). In the scenario of no treatment, a far greater proportion of HCV-infected PWID progress to these liver disease stages compared to when treatment is available, meaning that the baseline average cost per newly HCV-infected individual may be higher and the ICERs lower than we have calculated. Secondly, we have not captured the benefits of reduced transmission-namely that treating an increasing number of PWID will reduce the HCV prevalence among PWID and also the infection / re-infection rate. Modelling suggests that by treating 40/1000 PWID per year, HCV prevalence can be halved within 15 years $(49,50)$. This is likely to have a significant impact on total costs, as an increasing number of new infections are prevented and the epidemic is slowed, and is also likely to increase the cost-effectiveness of early-treatment compared to late-treatment, since early-treatment is more likely to occur before injecting cessation and would therefore have the most effect on the prevention of further transmissions. Further work should be undertaken to account for the effects of a dynamic infection rate on the cost-effectiveness of treatment. 


\section{Conclusion}

Treating HCV-infected PWID with new therapies is cost-effective, and could prevent a significant number of liver related deaths. Although late-treatment was the most cost-effective option, the cost per QALY gained for early-treatment compared to late-treatment is likely to be below unofficial Australian willingness to pay thresholds. The low cost per QALY for early-treatment in our model in Australia suggests the early-treatment of PWID may be similarly cost-effective in other jurisdictions.

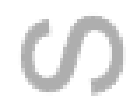

\section{Acknowledgements}

The authors gratefully acknowledge the contribution to this work through project funding from the Victorian Infectious Diseases Service Special Purpose Fund at Melbourne Health, and support to the Burnet Institute provided by the Victorian Government Operational Infrastructure Support Program. NS is the recipient of a Burnet Institute Jim and Margaret Beever fellowship; MH, JD and AT are the recipients of National Health and Medical Research Council fellowships. Disclosure of interests: JD, $\mathrm{MH}$ and the Burnet Institute receive investigator-initiated research funding from Gilead Sciences and AbbVie. AT is a consultant / advisor for Merck, Gilead, Abbvie, BMS and Roche diagnostics, has received research support from Gilead, Abbvie, Merck, BMS and is a speaker for BMS. DI has received lecture fees or consulting fees from AbbVie, Bristol-Myers Squibb, Gilead Sciences, Janssen Pharmaceuticals, Merck Sharp \& Dohme (Australia), and Roche Products. No pharmaceutical grants were received in the development of this study.

\section{References}

1. Hajarizadeh B, Grebely J, Dore GJ. Epidemiology and natural history of HCV infection. Nature Reviews Gastroenterology and Hepatology. 2013.

This article is protected by copyright. All rights reserved. 
2. The Kirby Institute. HIV, viral hepatitis and sexually transmissible infections in Australia Annual Surveillance Report 2014. The University of New South Wales, Sydney NSW 2052. 2014.

3. Shepard CW, Finelli L, Alter MJ. Global epidemiology of hepatitis C virus infection. The Lancet infectious diseases. 2005;5(9):558-67.

4. Nelson PK, Mathers BM, Cowie B, Hagan H, Des Jarlais D, Horyniak D, et al. Global epidemiology of hepatitis $B$ and hepatitis $C$ in people who inject drugs: results of systematic reviews. The Lancet. 2011;378(9791):571-83.

5. Aceijas C, Rhodes T. Global estimates of prevalence of HCV infection among injecting drug users. International Journal of Drug Policy. 2007;18(5):352-8.

6. Micallef JM, Kaldor JM, Dore GJ. Spontaneous viral clearance following acute hepatitis C infection: a systematic review of longitudinal studies. Journal of viral hepatitis. 2006;13(1):34-41.

$7 . \quad$ Hellard M, Doyle JS, Sacks-Davis R, Thompson AJ, McBryde E. Eradication of hepatitis C infection: The importance of targeting people who inject drugs. Hepatology. 2014;59(2):366-9.

8. Hellard M, Rolls DA, Sacks-Davis R, Robins G, Pattison P, Higgs P, et al. The impact of injecting networks on hepatitis $C$ transmission and treatment in people who inject drugs. Hepatology. 2014;60(6):1861-70.

9. Okanoue T, Sakamoto S, Itoh Y, Minami M, Yasui K, Sakamoto M, et al. Side effects of highdose interferon therapy for chronic hepatitis C. Journal of hepatology. 1996;25(3):283-91. 10. Manns MP, McHutchison JG, Gordon SC, Rustgi VK, Shiffman M, Reindollar R, et al. Peginterferon alfa- $2 b$ plus ribavirin compared with interferon alfa- $2 b$ plus ribavirin for initial treatment of chronic hepatitis C: a randomised trial. The Lancet. 2001;358(9286):958-65.

11. Dore GJ. The changing therapeutic landscape for hepatitis $C$. The Medical journal of Australia. 2012;196(10):629-32.

12. Walsh N, Lim M, Hellard M. Using a surveillance system to identify and treat newly acquired hepatitis C infection. Journal of gastroenterology and hepatology. 2008;23(12):1891-4.

13. Grebely J, Oser M, Taylor LE, Dore GJ. Breaking down the barriers to hepatitis C virus (HCV) treatment among individuals with HCV/HIV coinfection: action required at the system, provider, and patient levels. Journal of Infectious Diseases. 2013;207(suppl 1):S19-S25.

14. Grebely J, Dore GJ, editors. What is killing people with hepatitis C virus infection? Seminars in Liver Diseases; 2011.

15. Sievert W, Razavi H, Estes C, Thompson AJ, Zekry A, Roberts SK, et al. Enhanced antiviral treatment efficacy and uptake in preventing the rising burden of hepatitis $\mathrm{C}$-related liver disease and costs in Australia. Journal of gastroenterology and hepatology. 2014;29(S1):1-9.

16. Welfare AloHa. Cancer incidence projections, Australia, 2011 to 2020. CANCER SERIES. 2012(66).

17. Lawitz E, Poordad FF, Pang PS, Hyland RH, Ding X, Mo H, et al. Sofosbuvir and ledipasvir fixed-dose combination with and without ribavirin in treatment-naive and previously treated patients with genotype 1 hepatitis C virus infection (LONESTAR): an open-label, randomised, phase 2 trial. The Lancet. 2014;383(9916):515-23.

18. Gane EJ, Stedman CA, Hyland RH, Ding X, Svarovskaia E, Subramanian GM, et al. Efficacy of nucleotide polymerase inhibitor sofosbuvir plus the NS5A inhibitor ledipasvir or the NS5B nonnucleoside inhibitor GS-9669 against HCV genotype 1 infection. Gastroenterology. 2014;146(3):73643. e1.

19. Poordad F, Lawitz E, Kowdley KV, Cohen DE, Podsadecki T, Siggelkow S, et al. Exploratory study of oral combination antiviral therapy for hepatitis C. New England Journal of Medicine. 2013;368(1):45-53.

20. Leidner AJ, Chesson HW, Xu F, Ward JW, Spradling PR, Holmberg SD. Cost-effectiveness of hepatitis $C$ treatment for patients in early stages of liver disease. Hepatology. 2015.

21. Aitken CK, Lewis J, Tracy SL, Spelman T, Bowden DS, Bharadwaj M, et al. High incidence of hepatitis $C$ virus reinfection in a cohort of injecting drug users. Hepatology. 2008;48(6):1746-52. 
22. Degenhardt L, Hall W. Extent of illicit drug use and dependence, and their contribution to the global burden of disease. The Lancet. 2012;379(9810):55-70.

23. Visconti AJ, Doyle JS, Weir A, Shiell AM, Hellard ME. Assessing the cost-effectiveness of treating chronic hepatitis $C$ virus in people who inject drugs in Australia. Journal of gastroenterology and hepatology. 2013;28(4):707-16.

24. Wong J, Sylvestre D, Siebert U. Cost-effectiveness of treatment of hepatitis $C$ in injecting drug users. Hepatitis $C$ and injecting drug use: impact, costs and policy options. 2004:219.

25. Martin NK, Vickerman P, Miners A, Foster GR, Hutchinson SJ, Goldberg DJ, et al. Costeffectiveness of hepatitis $C$ virus antiviral treatment for injection drug user populations. Hepatology. 2012;55(1):49-57.

26. Horyniak D, Higgs $P$, Jenkinson $R$, Degenhardt $L$, Stoove $M$, Kerr $T$, et al. Establishing the Melbourne Injecting Drug User Cohort Study (MIX): rationale, methods, and baseline and twelvemonth follow-up results. Harm reduction journal. 2013;10:11.

27. Commonwealth of Australia Department of Health. Medicare Benefits Schedule Book. Available from URL http://www.mbsonline.gov.au/. April 2015.

28. Commonwealth of Australia Department of Health. Schedule of Pharmaceutical Benefits. Available from URL http://www.pbs.gov.au/. April 2015.

29. Fazito E, Cuchi P, Mahy M, Brown T. Analysis of duration of risk behaviour for key populations: a literature review. Sexually transmitted infections. 2012;88(Suppl 2):i24-i32.

30. Price RK, Risk NK, Spitznagel EL. Remission from drug abuse over a 25-year period: patterns of remission and treatment use. American journal of public health. 2001;91(7):1107.

31. Stoové MA, Dietze PM, Aitken CK, Jolley D. Mortality among injecting drug users in Melbourne: a 16-year follow-up of the Victorian Injecting Cohort Study (VICS). Drug and alcohol dependence. 2008;96(3):281-5.

32. Australian Bureau of Statistics (ABS). http://www.abs.gov.au/. 2014.

33. Grebely J, Pham ST, Matthews GV, Petoumenos K, Bull RA, Yeung B, et al. Hepatitis C virus reinfection and superinfection among treated and untreated participants with recent infection. Hepatology. 2012;55(4):1058-69.

34. McCaw R, Moaven L, Locarnini S, Bowden D. Hepatitis C virus genotypes in Australia. Journal of viral hepatitis. 1997;4(5):351-7.

35. Hellard M, Sacks-Davis R, Gold J. Hepatitis $C$ treatment for injection drug users: a review of the available evidence. Clinical Infectious Diseases. 2009;49(4):561-73.

36. Gane EJ, Stedman CA, Hyland RH, Sorensen RD, Symonds WT, Hindes R, et al., editors. Once daily PS1-7977 plus RBV: pegylated interferon-alfa not required for complete rapid viral response in treatment-naive patients with HCV GT2 or GT3. Hepatology; 2011: WILEY-BLACKWELL COMMERCE PLACE, 350 MAIN ST, MALDEN 02148, MA USA.

37. Chen J, Florian J, Carter W, Fleischer RD, Hammerstrom TS, Jadhav PR, et al. Earlier sustained virologic response end points for regulatory approval and dose selection of hepatitis $C$ therapies.

Gastroenterology. 2013;144(7):1450-5. e2.

38. Mondelli MU, Cerino A, Cividini A. Acute hepatitis C: diagnosis and management. Journal of hepatology. 2005;42(1):S108-S14.

39. Thein $\mathrm{HH}, \mathrm{Yi}$ Q, Dore GJ, Krahn MD. Estimation of stage-specific fibrosis progression rates in chronic hepatitis $\mathrm{C}$ virus infection: a meta-analysis and meta-regression. Hepatology.

2008;48(2):418-31.

40. National Centre in HIV Epidemiology and Clinical Research. Epidemiological and economic impact of potential increased hepatitis C treatment uptake in Australia. National Centre in HIV Epidemiology and Clinical Research, The University of New South Wales, Sydney, NSW. 2010.

41. Grieve R, Roberts J, Wright M, Sweeting M, DeAngelis D, Rosenberg W, et al. Cost effectiveness of interferon $\alpha$ or peginterferon $\alpha$ with ribavirin for histologically mild chronic hepatitis C. Gut. 2006;55(9):1332-8. 
42. Shepherd J, Jones J, Hartwell D, Davidson P, Price A, Waugh N. Interferon alfa (pegylated and non-pegylated) and ribavirin for the treatment of mild chronic hepatitis $\mathrm{C}$ : a systematic review and economic evaluation. Health Technology Assessment. 2007;11(11).

43. Wright M, Grieve R, Roberts J, Main J, Thomas H. Health benefits of antiviral therapy for mild chronic hepatitis $C$ : randomised control trial and economic evaluation. Health. 2006;10(21).

44. John-Baptiste AA, Tomlinson G, Hsu PC, Krajden M, Heathcote EJ, Laporte A, et al. Sustained responders have better quality of life and productivity compared with treatment failures long after antiviral therapy for hepatitis C. The American journal of gastroenterology. 2009;104(10):2439-48. 45. Bonkovsky HL, Snow KK, Malet PF, Back-Madruga C, Fontana RJ, Sterling RK, et al. Healthrelated quality of life in patients with chronic hepatitis $\mathrm{C}$ and advanced fibrosis. Journal of hepatology. 2007;46(3):420-31.

46. Independent Hospital Pricing Authority. National Hospital Cost Data Collection Australian Public Hospitals Cost Report 2011-2012, Round 16. Available from URL

http://www.ihpa.gov.au/internet/ihpa/publishing.nsf/content/nhcdc-lp. 2014.

47. Harrison M. Valuing the Future: the social discount rate in cost-benefit analysis-Productivity Commission Visiting Researcher Paper. 2010.

48. Scott N, Hellard M, McBryde E. Modelling hepatitis C virus transmission among people who inject drugs: assumptions, limitations and future challenges. Virulence. 2015(just-accepted):00-.

49. Martin NK, Vickerman P, Grebely J, Hellard M, Hutchinson SJ, Lima VD, et al. Hepatitis C virus treatment for prevention among people who inject drugs: Modeling treatment scale-up in the age of direct-acting antivirals. Hepatology. 2013;58(5):1598-609.

50. Hellard ME, Jenkinson R, Higgs P, Stoove MA, Sacks-Davis R, Gold J, et al. Modelling antiviral treatment to prevent hepatitis $\mathrm{C}$ infection among people who inject drugs in Victoria, Australia. The Medical journal of Australia. 2012;196(10):638-41.

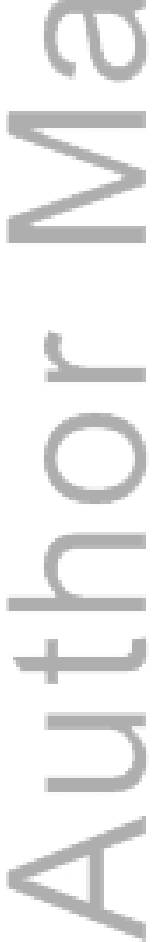

This article is protected by copyright. All rights reserved. 
Tables

Table 1: Demographic, HCV infection and HCV treatment model parameters

\begin{tabular}{|c|c|c|c|}
\hline Demographic information & Estimate & Symbol & References and comments \\
\hline Mean age at first injection & 17 years & & (26) \\
\hline Estimated time to first infection & 6.5 years & & $\begin{array}{l}\text { Using incidence of } 15.5 \text { per } 100 \text { person } \\
\text { years (range } 3-12 \text { years) (21). }\end{array}$ \\
\hline Estimated age of cohort to start model & 23.5 years & & From above. \\
\hline Duration of injecting career & 17 years & $1 / \eta$ & (29) \\
\hline $\begin{array}{l}\text { Annual probability of drug relapse to } \\
\text { IDU }\end{array}$ & 0.027 & 1-exp $\left(-r_{\text {relapse }}\right)^{\mathrm{a}}$ & $(24,30)$ \\
\hline \multicolumn{4}{|l|}{ Mortality ratios } \\
\hline \multicolumn{4}{|l|}{$\begin{array}{l}\text { Annual non-liver-related mortalities for } \\
\text { cohort PWID (per } 1000 \text { person years) }\end{array}$} \\
\hline $25-29$ years old $^{b}$ & 0.96 & 1-exp $\left(-\mu_{1}\right)$ & (31) \\
\hline $30-34$ years old & 1.12 & 1-exp $\left(-\mu_{2}\right)$ & (31) \\
\hline $35-44$ years old & 0.18 & 1-exp $\left(-\mu_{3}\right)$ & (31) \\
\hline $45-54$ years old & 0.22 & $1-\exp \left(-\mu_{4}\right)$ & \multirow{5}{*}{$\begin{array}{c}\text { Assumed to equal the general } \\
\text { Australian population. Values from } \\
\text { Victoria life tables (32), assuming } 60 \% \\
\text { male PWID (33). }\end{array}$} \\
\hline $55-64$ years old & 0.53 & $1-\exp \left(-\mu_{5}\right)$ & \\
\hline $65-74$ years old & 1.38 & 1-exp $\left(-\mu_{6}\right)$ & \\
\hline $75-84$ years old & 4.28 & 1-exp $\left(-\mu_{7}\right)$ & \\
\hline $85+$ years old & 14.96 & $1-\exp \left(-\mu_{8}\right)$ & \\
\hline \multicolumn{4}{|l|}{ HCV infection } \\
\hline Annual probability of PWID re-infection & 0.11 & $1-\exp (-\pi)$ & $\begin{array}{l}\text { Calibrated based on } 50 \% \text { chronic HCV } \\
\text { prevalence (Appendix A). Range } 0.08 \text { - } \\
0.16 \text {, corresponding to } 40 \% \text { and } 60 \% \\
\text { chronic HCV prevalence tested in } \\
\text { sensitivity analysis. }\end{array}$ \\
\hline Spontaneous clearance & 0.26 & $\delta$ & $\begin{array}{l}\text { (6) Range } 0.22-0.29 . \text { Uniform } \\
\text { distribution assumed for uncertainty } \\
\text { analysis. }\end{array}$ \\
\hline \multicolumn{4}{|l|}{ Genotype distribution in Australia } \\
\hline Genotype 1 & $55 \%$ & & (34) \\
\hline Genotype 2 & $7 \%$ & & (34) \\
\hline Genotype 3 & $38 \%$ & & (34) \\
\hline Treatment & & & \\
\hline
\end{tabular}

This article is protected by copyright. All rights reserved. 


\begin{tabular}{|r|c|c|c|}
\hline $\begin{array}{l}\text { Probability of PWID completing } \\
\text { treatment }\end{array}$ & 0.892 & $p_{\text {com }}$ & (35) \\
\hline Genotype weighted SVR probability & & $\alpha$ & $\begin{array}{c}\text { For Genotype 1: (17-19, 36); assumed } \\
\text { equally efficacious across genotypes. }\end{array}$ \\
\hline Moderate chronic HCV & 0.9 & $\alpha$ & $\begin{array}{c}\text { Assumed equally efficacious for mild } \\
\text { and moderate liver disease stages. }\end{array}$ \\
\hline Treatment duration & 0.9 & $\alpha$ (17-19, 37) \\
\hline Australian weighted average & weeks & $52 / \omega$ & \\
\hline Genotype 3 & 24 weeks & & \\
\hline
\end{tabular}

${ }^{a}$ Annual transition probabilities are converted to rates.

${ }^{\mathrm{b}}$ Extended to include individuals aged between $23.5-25$ year olds.

This article is protected by copyright. All rights reserved. 
Table 2: Liver disease and health state progression rates

\begin{tabular}{|c|c|c|c|c|c|}
\hline $\begin{array}{l}\text { Annual health state } \\
\text { transition probabilities }\end{array}$ & Estimate & $\begin{array}{c}\text { Distribution for } \\
\text { uncertainty analysis }\end{array}$ & $\begin{array}{l}\text { Standard } \\
\text { deviation }\end{array}$ & Rate parameter ${ }^{a}$ & Refs. \\
\hline Acute infection to mild (FO) & $52 / 12$ & 52/TNormal $(1,26)^{c}$ & $52 / 2$ & 1-exp $\left(-r_{A F 0}\right)$ & (38) \\
\hline \multicolumn{6}{|l|}{ Fo to F1 } \\
\hline Former PWID & 0.106 & TNormal(0.094,0.205) & 0.028 & $1-\exp \left(-r_{\mathrm{FOF} 1}\right)$ & (39) \\
\hline Current PWID & 0.116 & TNormal $(0.059,0.228)$ & 0.042 & 1-exp $\left(-\hat{r}_{\mathrm{FOF} 1}\right)$ & (39) \\
\hline \multicolumn{6}{|l|}{ F1 to $F 2$} \\
\hline Former PWID & 0.074 & TNormal $(0.064,0.175)$ & 0.028 & 1-exp $\left(-r_{F 1 F 2}\right)$ & (39) \\
\hline Current PWID & 0.085 & TNormal $(0.065,0.110)$ & 0.011 & 1-exp $\left(-\hat{r}_{\mathrm{F} 1 \mathrm{~F} 2}\right)$ & (39) \\
\hline \multicolumn{6}{|l|}{ F2 to $F 3$} \\
\hline Former PWID & 0.106 & TNormal $(0.092,0.187)$ & 0.033 & $1-\exp \left(-r_{F 2 F 3}\right)$ & (39) \\
\hline Current PWID & 0.085 & TNormal $(0.049,0.147)$ & 0.025 & $1-\exp \left(-\hat{r}_{F 2 F 3}\right)$ & (39) \\
\hline \multicolumn{6}{|l|}{ F3 to F4 } \\
\hline Former PWID & 0.105 & TNormal $(0.092,0.187)$ & 0.024 & 1-exp $\left(-r_{F 3 F 4}\right)$ & (39) \\
\hline Current PWID & 0.130 & TNormal $(0.053,0.319)$ & 0.067 & $1-\exp \left(-\hat{r}_{\mathrm{F} 3 \mathrm{~F} 4}\right)$ & (39) \\
\hline F4 to $D C$ & 0.037 & TNormal $(0.030,0.092)$ & 0.016 & 1-exp $\left(-r_{F 4 D C}\right)$ & (40) \\
\hline $\mathrm{F} 4$ to $\mathrm{HCC}$ & 0.010 & TNormal $(0.009,0.038)$ & 0.007 & 1-exp $\left(-r_{\mathrm{F} 4 \mathrm{HCC}}\right)$ & (40) \\
\hline $\mathrm{DC}$ to $\mathrm{HCC}$ & 0.068 & TNormal $(0.041,0.099)$ & 0.015 & 1-exp $\left(-r_{D C H C C}\right)$ & (40) \\
\hline DC to liver transplant & 0.033 & TNormal $(0.017,0.049)$ & 0.008 & 1-exp $\left(-r_{D C L T}\right)$ & (40) \\
\hline $\mathrm{DC}$ to death & 0.138 & TNormal $(0.074,0.202)$ & 0.032 & 1-exp $\left(-r_{D C \text { death }}\right)$ & (40) \\
\hline HCC to liver transplant & 0.100 & TNormal $(0.050,0.180)$ & 0.033 & 1-exp $\left(-r_{\text {HCCLT }}\right)$ & (40) \\
\hline HCC to death & 0.605 & TNormal $(0.545,0.676)$ & 0.033 & 1-exp $\left(-r_{\text {Hccdeath }}\right)$ & (40) \\
\hline $\begin{array}{l}\text { Liver transplant to death in } \\
\text { year } 1\end{array}$ & 0.169 & TNormal $(0.127,0.210)$ & 0.021 & 1-exp $\left(-r_{\text {LT1death }}\right)$ & (40) \\
\hline $\begin{array}{l}\text { Liver transplant to death in } \\
\text { years } 2+\end{array}$ & 0.034 & TNormal $(0.024,0.043)$ & 0.005 & 1-exp $\left(-r_{\text {LT2death }}\right)$ & (40) \\
\hline
\end{tabular}

${ }^{a}$ Annual transition probabilities are converted to rates; normally distributed parameters are converted to log-normal parameters.

${ }^{\mathrm{b}}$ Mean time in acute phase 12 weeks; range 1 week -6 months; standard deviation 2 weeks.

${ }^{c}$ TNormal(a,b), Normal distribution truncated between $a$ and $b$.

This article is protected by copyright. All rights reserved. 
Table 3: Health utilities and the annual and one-off costs associated with managing chronic HCV infection and treatment for various stages of liver disease.

\begin{tabular}{|c|c|c|c|c|c|}
\hline Health state utilities & Estimate & $\begin{array}{c}\text { Distribution for } \\
\text { uncertainty analysis }\end{array}$ & $\begin{array}{l}\text { Standard } \\
\text { deviation }\end{array}$ & Symbol & Refs. \\
\hline $\begin{array}{l}\text { Spontaneous viral clearance, never } \\
\text { infected }\end{array}$ & 0.93 & TNormal $(0.928,0.932)$ & 0.01 & q_S & (40) \\
\hline \multicolumn{6}{|l|}{ Sustained virological response } \\
\hline After early-treatment (F0) & 0.93 & TNormal(q_F012,q_S) & 0.01 & q_svr0 & $(41-43)$ \\
\hline fter late-treatment (F2-F3) & 0.93 & TNormal(q_F012,q_S) & 0.01 & q_svr2 & $\begin{array}{c}\text { Assumed } \\
\text { to } \\
\text { improve } \\
\text { following } \\
\text { SVR (44, } \\
45 \text { ) }\end{array}$ \\
\hline Acute HCV & 0.77 & TNormal(0,q_s) & 0.12 & q_A & \\
\hline Mild chronic HCV (F0/F1/F2) & 0.77 & TNormal(0,q_S) & 0.12 & q_F012 & $(41-43)$ \\
\hline Moderate chronic HCV (F3) & 0.66 & TNormal(0,q_F012) & 0.15 & q_F3 & $(41-43)$ \\
\hline Compensated cirrhosis (F4) & 0.55 & TNormal(0,q_F3) & 0.24 & q_F4 & $(41-43)$ \\
\hline Decompensated cirrhosis/liver failure & 0.45 & TNormal(0,q_F4) & 0.14 & q_DC & $(41-43)$ \\
\hline Hepatocellular carcinoma & 0.45 & TNormal(0,q_F4) & 0.14 & q_HCC & $(41-43)$ \\
\hline Liver transplantation year 1 & 0.45 & TNormal(q_HCC,1) & 0.14 & q_LT1 & $(41-43)$ \\
\hline Liver transplantation year $2+$ & 0.67 & TNormal(q_LT1,1) & 0.14 & q_LT2 & $(41-43)$ \\
\hline \multicolumn{6}{|l|}{ During treatment } \\
\hline Early-treatment & 0.77 & TNormal(q_F012,q_S) & 0.12 & q_T0 & Assumed \\
\hline Late-treatment & 0.66 & TNormal(q_F3,q_S) & 0.15 & $\mathrm{q}_{-} \mathrm{T} 2$ & Assumed \\
\hline Type of cost & & & $\begin{array}{r}\text { Valt } \\
\text { (2014 Au } \\
\text { dolla }\end{array}$ & $\begin{array}{l}\text { e } \\
\text { tralian } \\
\text { rs) }\end{array}$ & Refs. \\
\hline \multicolumn{3}{|c|}{ Annual costs of managing chronic HCV } & & & $(27,28)$ \\
\hline \multicolumn{3}{|c|}{ Mild chronic HCV (F0-F2) } & & $\$ 446.70$ & $(27,28)$ \\
\hline \multicolumn{3}{|c|}{ Moderate chronic HCV (F3) } & & $\$ 690.85$ & $(27,28)$ \\
\hline \multicolumn{3}{|c|}{ Compensated cirrhosis (F4) } & & $\$ 935.05$ & $(27,28)$ \\
\hline \multicolumn{6}{|c|}{ Decompensated cirrhosis (DC) } \\
\hline & & $\begin{array}{l}\text { Hepatic } \\
\text { Encephalopathy }\end{array}$ & $\$ 20,053.03$ & & $(27,28)$ \\
\hline
\end{tabular}




\begin{tabular}{|c|c|c|c|}
\hline & $\begin{array}{l}\text { Diuretic Sensitive } \\
\text { Ascites }\end{array}$ & $\$ 3,792.38$ & $(27,28)$ \\
\hline & Refractory Ascites & $\$ 29,264.28$ & $(27,28)$ \\
\hline & Variceal Haemorrhage & $\$ 68,567.43$ & $(27,28)$ \\
\hline & Weighted average & $\$ 15,202.43$ & \\
\hline Hepatocellular carcinoma (HCC) & & $\$ 10,759.75$ & $(27,28)$ \\
\hline \multicolumn{4}{|l|}{ One-off costs of transition between states } \\
\hline Initial diagnosis of HCV & & $\$ 936.63$ & $(27,28)$ \\
\hline Achieving SVR from treatment & & $\$ 303.55$ & $(27,28)$ \\
\hline Transition to F4 & & $\$ 565.67$ & $(27,28)$ \\
\hline Transition to HCC & & $\$ 970.20$ & $(27,28)$ \\
\hline Liver transplant & & $\$ 145,565.00$ & (46) \\
\hline \multicolumn{4}{|l|}{ Costs associated with treatment } \\
\hline Mild or moderate HCV & & & \\
\hline & Genotype 1 or 2 & $\$ 51,779.60$ & $(27,28)$ \\
\hline & Genotype 3 & $\$ 102,377.15$ & $(27,28)$ \\
\hline 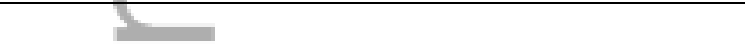 & Weighted average & $\$ 71,006.67$ & \\
\hline \multicolumn{4}{|l|}{ Other costs } \\
\hline $\begin{array}{r}\text { Additional annual costs of care for PWID with } \\
\text { chronic HCV }\end{array}$ & & $\$ 34.22$ & $(27,28)$ \\
\hline
\end{tabular}

This article is protected by copyright. All rights reserved. 
Table 4: Modelled costs, QALYs, life expectancies and ICERs for treating PWID with chronic HCV. Point estimates represent outcomes using point estimate parameters; ranges represent $95 \%$ confidence intervals (Cls) from the Monte Carlo uncertainty analysis.

\begin{tabular}{|c|c|c|c|c|c|c|}
\hline $\begin{array}{c}\frac{1}{\text { Point }} \\
\text { estimates } \\
\underline{(95 \% \mathrm{Cls})}\end{array}$ & $\begin{array}{l}\text { Cost per } \\
\text { infected } \\
\text { person }\end{array}$ & $\begin{array}{c}\text { QALYs per } \\
\text { infected } \\
\text { person }\end{array}$ & $\begin{array}{c}\text { Life expectancy } \\
\text { of an infected } \\
\text { person }\end{array}$ & $\begin{array}{c}\text { ICER compared } \\
\text { to no } \\
\text { treatment }\end{array}$ & $\begin{array}{l}\text { ICER compared } \\
\text { to next best } \\
\text { case }\end{array}$ & $\begin{array}{c}\text { Liver related } \\
\text { deaths } \\
\text { expected per } \\
100 \text { newly } \\
\text { infected PWID }\end{array}$ \\
\hline $\begin{array}{l}\text { Base case } \\
\text { (no antivira } \\
\text { treatment) }\end{array}$ & $\begin{array}{c}\$ 21,877 \\
(\$ 20,618- \\
27,294)\end{array}$ & $\begin{array}{c}16.45 \\
(11.19-18.13)\end{array}$ & $\begin{array}{c}67.97 \\
(63.55-68.27)\end{array}$ & Reference case & & $\begin{array}{c}40 \\
(39-56)\end{array}$ \\
\hline $\begin{array}{l}\text { Late- } \\
\text { treatmen }\end{array}$ & $\begin{array}{c}\$ 37,009 \\
(\$ 34,754- \\
43,772)\end{array}$ & $\begin{array}{c}19.43 \\
(15.84-21.44)\end{array}$ & $\begin{array}{c}74.14 \\
(73.11-74.44)\end{array}$ & $\begin{array}{c}\$ 5,078 \\
(\$ 2,847-5,295)\end{array}$ & $\begin{array}{c}\text { No treatment v } \\
\text { late-treatment } \\
\$ 5,078 \\
(\$ 2,847-5,295)\end{array}$ & $\begin{array}{c}8 \\
(7-13)\end{array}$ \\
\hline Early- & $\begin{array}{r}\$ 75,803 \\
=(\$ 75,410- \\
=\quad 79,335)\end{array}$ & $\begin{array}{c}21.70 \\
(20.58-22.09)\end{array}$ & $\begin{array}{c}74.47 \\
(73.58-74.56)\end{array}$ & $\begin{array}{l}\$ 10,272 \\
(\$ 5,689- \\
13,690)\end{array}$ & $\begin{array}{c}\text { Early v late- } \\
\text { treatment } \\
\$ 17,090 \\
(\$ 7,926- \\
63,282)\end{array}$ & $\begin{array}{c}7 \\
(6-11)\end{array}$ \\
\hline
\end{tabular}

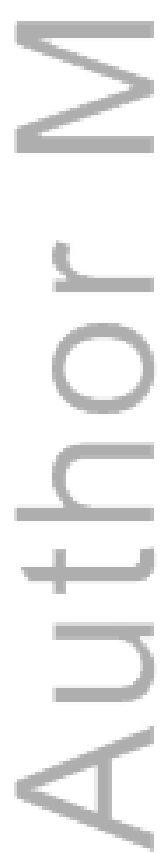

This article is protected by copyright. All rights reserved. 


\section{Figure legends}

Figure 1: Model schematic.

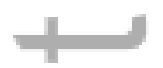

Figure 2: Cost-effectiveness plane showing simulation results and averages for early- and latetreatment compared to no treatment (top left); and cost-effectiveness acceptability curves for latetreatment compared to no treatment (top right), early-treatment compared to late-treatment (bottom left), and early-treatment compared to no treatment (bottom right).

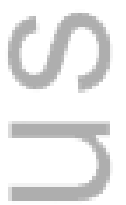

Figure 3: Sensitivity of the ICER for early-treatment compared to no treatment (left); and latetreatment compared to no treatment (right), to changes in: the cost of DAAs, initial prevalence (reinfection rate), the discounting rate, re-treatment availability, the percentage who achieve a sustained viral response (SVR) from treatment, the average length of injecting career, the potential for former PWID to relapse into active injecting, treatment duration, and the health utility following late-treatment.

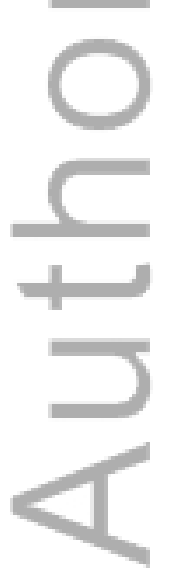

This article is protected by copyright. All rights reserved. 


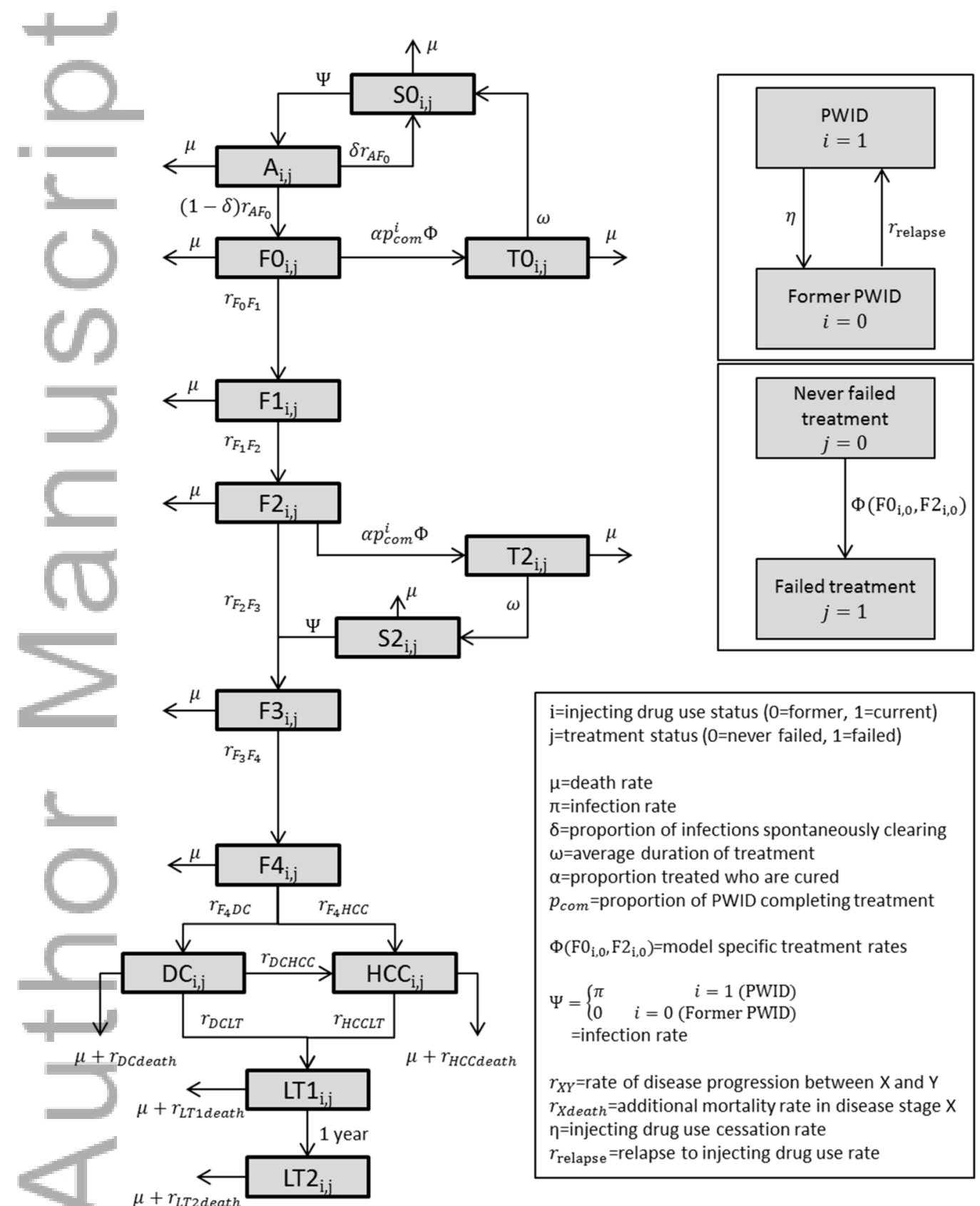

JGH_13223_F1.tif 

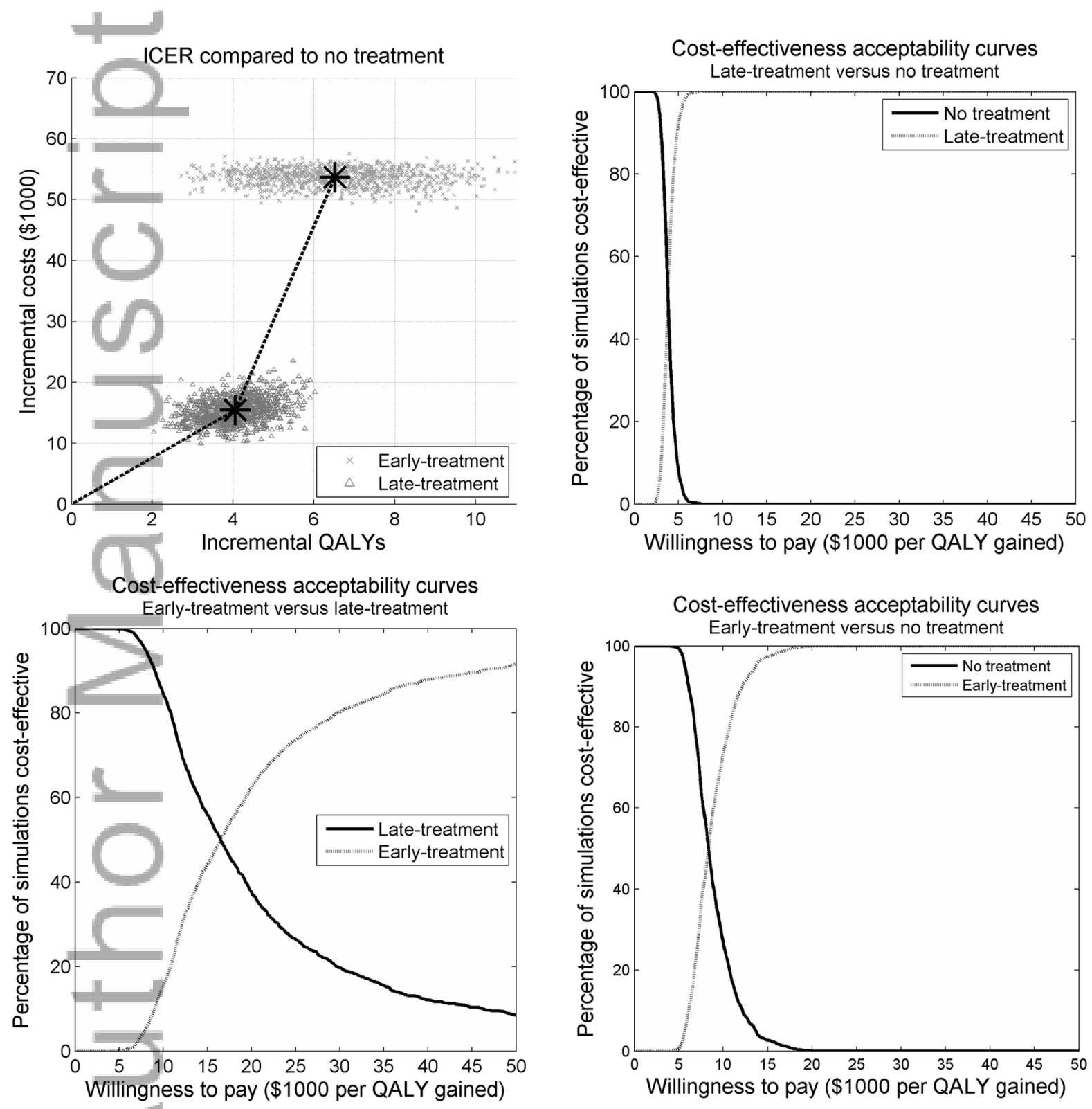

JGH_13223_F2.tif

This article is protected by copyright. All rights reserved. 
Sensitivity of ICER

Late-treatment versus no treatment

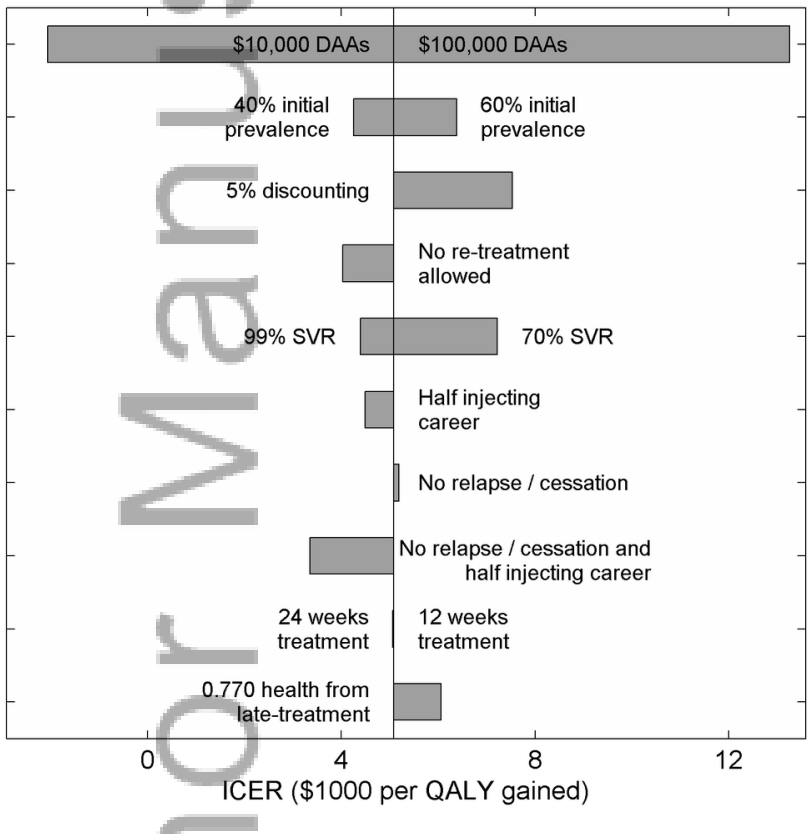

JGH_13223_F3.tif
Sensitivity of ICER

Early-treatment versus late-treatment

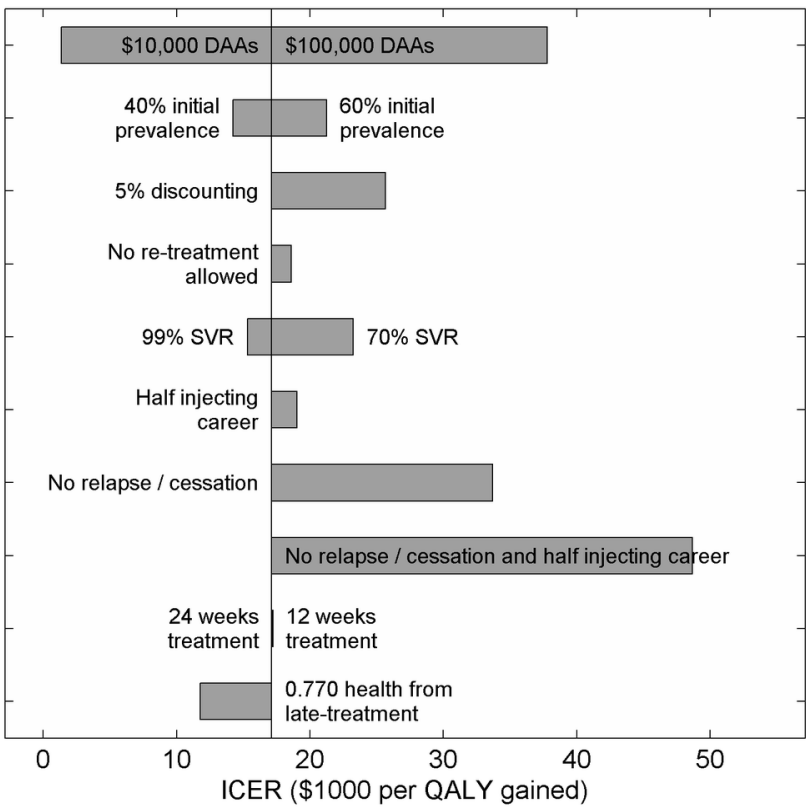

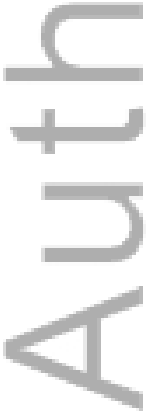

This article is protected by copyright. All rights reserved. 


\section{University Library}

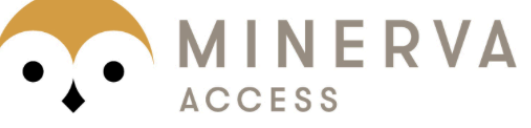

A gateway to Melbourne's research publications

Minerva Access is the Institutional Repository of The University of Melbourne

Author/s:

Scott, N;Iser, DM;Thompson, AJ;Doyle, JS;Hellard, ME

Title:

Cost-effectiveness of treating chronic hepatitis $\mathrm{C}$ virus with direct-acting antivirals in people who inject drugs in Australia

Date:

2016-04-01

Citation:

Scott, N., Iser, D. M., Thompson, A. J., Doyle, J. S. \& Hellard, M. E. (2016). Costeffectiveness of treating chronic hepatitis $C$ virus with direct-acting antivirals in people who inject drugs in Australia. JOURNAL OF GASTROENTEROLOGY AND HEPATOLOGY, 31 (4), pp.872-882. https://doi.org/10.1111/jgh.13223.

Persistent Link:

http://hdl.handle.net/11343/291126 